\title{
Sea ice microbial communities. VI. Growth and primary production in bottom ice under graded snow cover
}

\author{
Sarah McGrath Grossi ${ }^{1}$, Steven T. Kottmeier ${ }^{1}$, Richard L. Moe ${ }^{2}$, Gordon T. Taylor ${ }^{3}$ \\ \& Cornelius W. Sullivan ${ }^{1}$ \\ ${ }^{1}$ Marine Biology Research Section, Department of Biological Sciences, University of Southern California, Los Angeles, \\ California 90089-0371, USA \\ ${ }^{2}$ Department of Botany, University of California, Berkeley, California 94704, USA \\ ${ }^{3}$ Department of Geophysics, Division of Natural Sciences, University of Hawaii at Manoa, Honolulu, Hawaii 96822, USA
}

\begin{abstract}
The effect of under-ice irradiance on in situ growth and production of sea ice microalgae was investigated at McMurdo Sound, Antarctica in 1982. Five $100 \mathrm{~m}^{2}$ quadrats on annual ice were delimited in early October with $0,5,10,25$ and $100 \mathrm{~cm}$ snow cover; under-ice irradiances ranged from $<0.02$ to $100 \mu \mathrm{E} \mathrm{m}^{-2} \mathrm{~s}^{-1}$. Standing crop, growth rate and photosynthetic rate were greatest in snowfree ice (Q-0) where chlorophyll a concentration increased from 0.1 to $76 \mathrm{mg} \mathrm{m}^{-2}$ in the platelet layer $\left(\mu=0.41 \mathrm{~d}^{-1}\right)$ and from 0.05 to $9 \mathrm{mg} \mathrm{m} \mathrm{m}^{-2}$ in bottom congelation ice $\left(\mu=0.29 \mathrm{~d}^{-1}\right)$ over $5 \mathrm{wk}$. Blooms occurred later in quadrats with 5,10 , and $25 \mathrm{~cm}$ snow cover; however, growth rates were less than half that in Q-0. We tested the hypothesis that microalgal standing crop in bottom ice approximates cumulative production. Peak algal standing crop at Q-0 was estimated to be $3.2 \mathrm{~g} \mathrm{C} \mathrm{m}^{-2}$, based on a carbon to chlorophyll ratio of 38 . However, net primary production based on in situ measurements of photosynthetic rate was 10 -fold higher, at $41 \mathrm{~g} \mathrm{C} \mathrm{m}^{-2}$ This finding suggests that previous estimates of sea ice production must be revised sharply upward.
\end{abstract}

\section{INTRODUCTION}

Sea ice in the Arctic and Antarctic provides a variety of habitats for growth of microalgae. Microalgal communities have been described from surface, interior and bottom regions of land-fast and pack ice, and in frazil, congelation and platelet ice layers (Apollonio 1961, Meguro 1962, Bunt \& Wood 1963, Horner \& Alexander 1972, Ackley et al. 1979 and others). Autumn blooms occur in newly formed ice at Lutzholm Bay (Hoshiai 1977) and mid-summer blooms on the surface of ice near the Palmer Peninsula (Burkholder \& Mandelli 1965). Highest standing crops, however, and the most extensively studied sea ice communities occur at the bottom of annual sea ice in spring.

The high density of bottom ice microalgae suggests that this community represents an important source of carbon to polar ecosystems. Yet quantitative measurements of in situ production are few (Horner \& Schrader 1982, Palmisano et al. 1985a). Particularly in the Antarctic, estimates of annual sea ice production have usually been based upon standing crop of chlorophyll a prior to summer ice melt (Bunt 1963, Sullivan et al. 1985). Implicit in these estimates is the assumption that losses from the sea ice habitat (e.g. by grazing and sinking) are negligible due to the physical confinement of cells in ice (Bunt \& Lee 1970). The validity of this assumption has not been adequately tested.

In 1982, we tested the hypothesis that chlorophyll standing crop in sea ice prior to summer melt approximates cumulative production. Over the 3 mo period, in situ rates of primary production $\left(\mathrm{NaH}^{14} \mathrm{CO}_{3}\right.$ method) in bottom ice at McMurdo Sound, Antarctica were compared with net increase in chlorophyll $a$.

We also tested the influence of the in situ light field on microalgal growth and production. Light has been proposed as the major factor limiting growth in bottom sea ice communities (Bunt 1971, Fogg 1977, Horner \& Schrader 1982, Palmisano \& Sullivan 1982). Downwelling irradiance is attenuated by snow cover, sea ice, and microalgae, so that under-ice irradiance is typically less than $1 \%$ of surface (Maykut \& Grenfell 1975, 
Sullivan et al. 1982, 1984). Moreover, the spectral composition of light shifts as it passes through sea ice, towards a predominance of blue-green wavelengths (450 to $550 \mathrm{~nm}$ ) at the 1ce undersurface (Maykut \& Grenfell 1975, Sullivan et al. 1984, Palmisano et al. 1987). By contrast, peak chlorophyll absorption occurs around 420 and $675 \mathrm{~nm}$.

In the present study, irradiance to bottom ice communities was controlled by maintaining sea ice quadrats under different snow covers ranging from 0 to $100 \mathrm{~cm}$ (Palmisano et al. 1987). The effect of this gradient on species composition of microalgae (Grossi \& Sullivan, unpubl.) and on bacterial growth (Kottmeier et al. 1987) are reported elsewhere. Here we present the effects of in situ irradiance on growth and primary production in bottom sea ice communities.

\section{METHODS}

Field studies were conducted on annual sea lce north of Cape Armitage, Ross Island (Fig. 1) over a $20 \mathrm{~m}$ water column. Ten $100 \mathrm{~m}^{2}$ quadrats were demarcated on 9 October 1982, near the site of a 1981 light perturbation experiment (Palmisano et al. 1985a). Natural

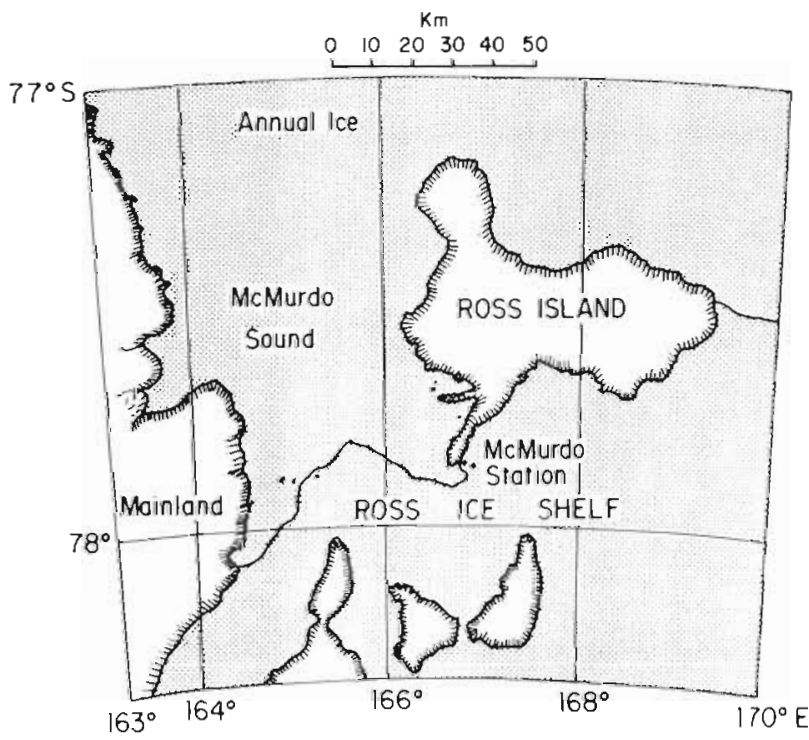

Fig 1. Map of McMurdo Sound, Antarctica, site of expenmental study

snow cover was approxumately $25 \mathrm{~cm}$. Duplicate quadrats were set up with $0,5,10,25$ and $100 \mathrm{~cm}$ snow cover; snow depths were maintained untul the ice began to melt in late December. One set of quadrats (Q-0, Q-5, Q-10, Q-25 and Q-100) was sampled extensively to monitor microalgal growth and production as described in this paper. The second set was used in a complementary study to quantify attenuation of downwelling irradiance by snow, sea ice and ice microalgae (Sullivan et al. 1984. Palmisano et al. 1987)

Sampling. Congelation ice was sampled prior to perturbation and subsequently on 25 October, 13 November, 4 or 7 December, and 24 or 26 December for determination of microalgal biomass. Triplicate ice cores were taken from each quadrat using a SIPRE auger (Geo-Test) with $7.5 \mathrm{~cm}$ diameter barrel; sections of ice were cut with a stainless steel handsaw.

Initially only the bottom $20 \mathrm{~cm}$ of congelation ice was retained, since a previous study had shown that this segment contains $>99 \%$ of chlorophyll a (Palmisano \& Sullıvan 1983). Beginning on 13 November, one segment corresponding to the bottom $20 \mathrm{~cm}$ of ice on 25 October and a second segment representing new ice growth were separately retained. This sampling scheme accounted for the effects of variable ice accretion on estimates of standing stock.

In 1982, an extensive $(0.5$ to $0.8 \mathrm{~m}$ ) layer of loosely consolidated platelet ice, not observed at this site in 1980 or 1981 (Sullivan et al. 1982) was present beneath the hard congelation ice. Divers collected samples of platelet ice in quadrats Q-0 and Q-5 by pushing a Nalgene jar (7.6 l) up into this layer.

Biomass analyses. Congelation and platelet ice samples were melted in the dark at $0^{\circ} \mathrm{C}$. For determination of pigments, duplicate subsamples were collected on glass fiber filters (Whatman GF/C) and frozen until fluorometric analysis of chlorophyll a (chl a) and phaeopigments (phaeo) by the method of HolmHansen et al. (1965). Subsamples for determination of particulate organic carbon (POC) were collected on glass fiber fulters and frozen until analysis by the wet oxidation technique (Menzel \& Vaccaro 1964) using an Ocean International Corporation infrared gas analyzer (College Station, Texas, USA).

Physical measurements. Photosynthetically active radiation (PAR between 400 and $700 \mathrm{~nm}$ ) was measured beneath the ice between 1100 and $1300 \mathrm{~h}$ by divers using a scalar irradiance meter (spherical collector) (QSI-140, Biospherical Instruments, San Diego, Californa, USA) or a spectroradiometer with cosine collector (MER-100, Biospherical Instruments; Palmisano et al. 1987). Congelation ice thickness was determined by dropping a weighted tape measure (Geo-Test) through holes where cores of congelation ice were taken. Total ice depth (congelation and platelet) was determined by a depth transducer on the spectroradiometer. Platelet ice thickness was approximated as the dufference between total and congelation ice thicknesses.

Photosynthetic rate experiments. In situ photosynthetic rates were determined for samples of platelet and congelation ice from $\mathrm{Q}-0$ and $\mathrm{Q}-5$, using a modifi 
cation of the $\mathrm{NaH}^{14} \mathrm{CO}_{3}$ method (Steemann-Nielsen 1952, Strickland \& Parsons 1972). The complexity of the sea ice/brine matrix presents special problems in quantifying rates of metabolism. Because we wished to mimic as closely as possible conditions in the ice microenvironment, we used intact samples of sea ice in our experiments. We recognize as a shortcoming of our method the uncertain distribution of radiotracer between seawater and sea ice phases; however, we chose this uncertainty over deliberate alteration of the ice microenvironment, e.g. by meltdown prior to incubation.

Duplicate ice cores were collected and the bottom $5 \mathrm{~cm}$ segments were removed and quartered; the volume of each quarter was approximately $40 \mathrm{~cm}^{3}$. Two quarters from each core were used in a related study to measure bacterial incorporation of ${ }^{3} \mathrm{H}$-thymidine (Kottmeier et al. 1987). Of the remaining quarters, one was placed in a transparent ('Light') polymethylpentene jar (Nalgene) and the other in a ('Dark') jar covered with electrical tape. Filtered seawater was added to fill the jars $175 \mathrm{ml}$ capacity. Samples were inoculated with $\mathrm{NaH}^{14} \mathrm{CO}_{3}$ (New England Nuclear) to a final concentration of $0.046 \mu \mathrm{Ci} \mathrm{ml}^{-1}\left(1.69 \mathrm{~Bq} \mathrm{ml}{ }^{-1}\right)$ and kept at $0{ }^{\circ} \mathrm{C}$ in the dark for approximately 10 min until placement by divers for in situ incubation.

Duplicate platelet samples were collected by divers and the interstitial water was decanted. A measured amount of interstitial water plus a variable amount of platelets was added to light and dark jars and $\mathrm{NaH}^{14} \mathrm{CO}_{3}$ injected as above. Jars were secured in a Plexiglas frame and placed, inverted, beneath the quadrat from which they had been taken. Preliminary time course experiments showed that $\mathrm{NaH}^{14} \mathrm{CO}_{3}$ uptake was linear for up to $30 \mathrm{~h}$; formalin-killed and dark controls were 5 and $10 \%$ respectively, of samples incubated in the light. Quadrat samples were incubated for $24 \mathrm{~h}$, then retrieved and the incubation terminated by addition of formalin to a final concentration of $2 \%$. Samples were transported at $0^{\circ} \mathrm{C}$ in the dark to the laboratory, where they were allowed to melt at room temperature prior to analysis.

Seawater samples were collected from $3 \mathrm{~m}$ depth using a Kemmerer PVC water sampler. Four light and 2 dark bottles (Wheaton $300 \mathrm{ml}$ ) were incubated with $\mathrm{NaH}^{14} \mathrm{CO}_{3}$ to a final concentration of $0.067 \mu \mathrm{Ci} \mathrm{m} l^{-1}$ $\left(2.46 \mathrm{~Bq} \mathrm{ml}{ }^{-1}\right)$. The light bottles were suspended beneath Q-0 and the dark bottles beneath the dive hole for 24 to $48 \mathrm{~h}$. Following incubation, the bottles were transported at $0^{\circ} \mathrm{C}$ in the dark to the laboratory for immediate analysis.

Photosynthetic rate sample analysis. Duplicate 2 to $10 \mathrm{ml}$ subsamples were filtered onto $0.2 \mu \mathrm{m}$ Nuclepore membrane filters and frozen for analysis of chlorophyll $a$. The remaining volume was filtered, either totally or in replicate subsamples, through 1.0 and $0.2 \mu \mathrm{m}$ Nuclepore filters. Filters were rinsed twice with $10 \mathrm{ml}$ chilled $0.2 \mu \mathrm{m}$ filtered seawater, fumed over concentrated $\mathrm{HCl}$ overnight to remove unincorporated radiocarbon, and placed in Aquasol I (New England Nuclear) liquid scintillation cocktail for radioassay by a Beckman LSC-100 instrument. For determination of photosynthetically fixed dissolved organic carbon (PDOC), a $5 \mathrm{ml}$ subsample of the filtrate was acidified to $\mathrm{pH} 2$ with $0.1 \mathrm{~N} \mathrm{HCl}$ and mixed uncapped on a rotary shaker for $12 \mathrm{~h}$ to drive off ${ }^{14} \mathrm{CO}_{2}$. Triplicate $1 \mathrm{ml}$ subsamples were then radioassayed. CPMs were converted to DPMs using the external standards ratio method.

Photosynthetic rate calculations. Alkalinity (American Public Health Association 1971) and pH (Strickland \& Parsons 1972) were determined for platelet interstitial water and seawater, and dissolved inorganic carbon estimated according to Wood (1975). Photosynthetic rates $\left(\mathrm{mg} \mathrm{C} \mathrm{m}^{-3} \mathrm{~d}^{-1}\right)$ were computed as the total amount of ${ }^{14} \mathrm{C}$ fixed (sum of particulate ${ }^{14} \mathrm{C}$ on 1.0 and $0.2 \mu \mathrm{m}$ filters plus dissolved ${ }^{14} \mathrm{C}$ in the filtrate) in the light minus that fixed in the dark, using a factor of 1.05 to correct for isotope discrimination (Strickland \& Parsons 1972). We do not report separately the fraction of PDOC as percent extracellular release because incubations were terminated by the addition of formaldehyde, a treatment which has been shown to result in a significant loss of fixed, filter-retainable ${ }^{14} \mathrm{C}$ in natural phytoplankton assemblages (Silver \& Davoll 1978).

Integrated daily production ( $\mathrm{mg} \mathrm{m}^{-2}$ ) was calculated from photosynthetic rate as follows. For congelation sea ice, $\mathrm{mg} \mathrm{C} \mathrm{m} \mathrm{m}^{-3} \mathrm{~d}^{-1}$ was multiplied first by a factor $\mathrm{F}$ to correct for seawater dilution of the ice sample $(F=$ total sample volume divided by meltwater volume) and then by the depth of the experimental ice cube $(0.05 \mathrm{~m})$. For platelet ice, the proportional volume of ice to platelet water in the sample was determined and multiplied by a correction factor to give a 20:80 ice : interstitial water ratio as reported by Bunt (1963) and confirmed by Kottmeier (unpubl. data). Integrated production was calculated as the product of corrected photosynthetic rate and depth of the platelet layer. For seawater, photosynthetic rate was multiplied by $20 \mathrm{~m}$, total depth of the water column at our study site.

\section{RESULTS}

\section{Light}

Details on the spectral composition of under-ice irradiance are presented in a companion paper (Palmisano et al. 1987). Manipulation of snow cover pro- 
duced a gradient in irradiances ranging from $90 \mu \mathrm{E} \mathrm{m}^{-2}$ $\mathrm{s}^{-1}$ beneath $\mathrm{Q}-0$ (no snow cover) to $<0.02 \mu \mathrm{E} \mathrm{m} \mathrm{m}^{-2} \mathrm{~s}^{-1}$ beneath Q-100 (100 cm snow cover) in early November (Table 1). This range of irradiances best represents initial light conditions prior to and unaffected by algal

Table 1. Under-ice irradiances $\left(\mu \mathrm{E} \mathrm{m}^{-2} \mathrm{~s}^{-1}\right)$ measured beneath platelet ice by spectroradiometer. Irradiance beneath $\mathrm{Q}-100$ was consistently below limits of detection $\left(<0.02 \mu \mathrm{E} \mathrm{m}^{-2} \mathrm{~s}^{-1}\right)$. Results are reprinted from Table 2 in Palmisano et al. (1987)

\begin{tabular}{|rrrrrr|}
\hline Date & Q-0 & Q-5 & Q-10 & Q-25 & Q-100 \\
\hline 9 Nov & 90.5 & 0.7 & 0.4 & 0.1 & $<0.02$ \\
19 Nov & 4.7 & 0.8 & 4.1 & 0.3 & $<0.02$ \\
30 Nov & 136.0 & 6.2 & 1.1 & 0.2 & $<0.02$ \\
20 Dec & 74.0 & 4.6 & 42.0 & 3.0 & $<0.02$ \\
\hline
\end{tabular}

absorption. PAR beneath Q-0 declined sharply between 9 and 19 November; an irradiance spectrum on the latter date showed a pattern characteristic of absorption by algal pigments (Palmisano et al. 1987) and divers reported a visible discoloration of the ice undersurface. Irradiance in Q-0 increased again to $>100 \mu \mathrm{E} \mathrm{m} \mathrm{m}^{-2} \mathrm{~s}^{-1}$ by 30 November, presumably due to loss of platelet microalgae described below.

\section{Ice growth}

Within 1 mo of snow removal, congelation and platelet ice at Q-0 reached maximum thicknesses of $2.2 \mathrm{~m}$ and $0.45 \mathrm{~m}$, respectively (Fig. 2). By contrast, sea

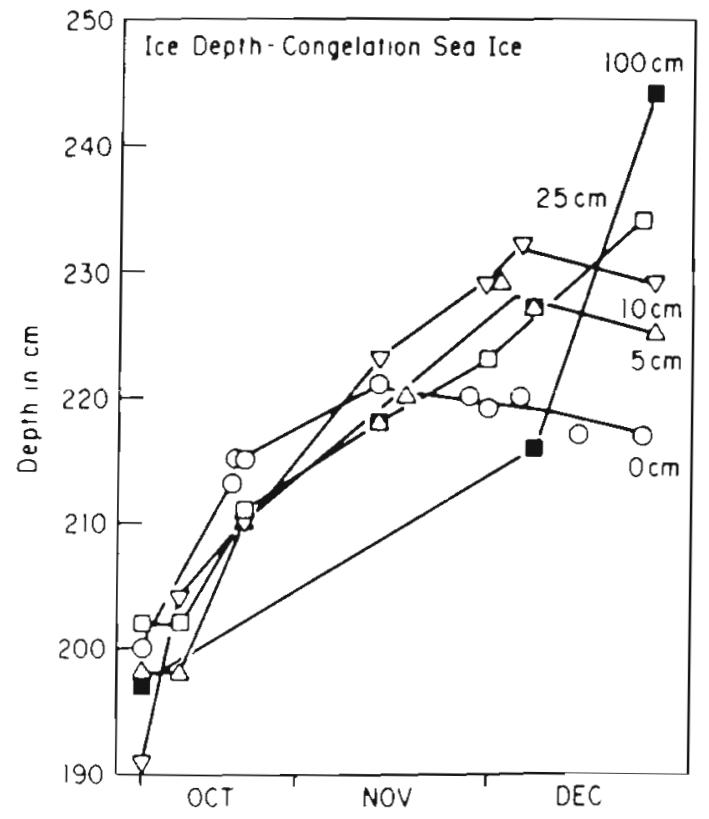

ice in the other quadrats continued to increase at least through early December. Final congelation and platelet ice thicknesses at Q-5 through Q-100 were $2.33 \pm 0.82 \mathrm{~m}$ and $0.73 \pm 0.10 \mathrm{~m}$, respectively.

Diver observations suggested that platelet ice thicknesses derived from depth measurements by the spectroradiometer were overestimates, particularly at Q-0. A series of photographs demonstrates the inconsistencies. In Fig. 3A, the spectroradiometer is shown on 9 November beneath platelet ice at Q-5 that both divers and the depth transducer agreed was approximately $45 \mathrm{~cm}$ thick. On the same date, platelet ice at Q-0 looked much the same, except that it was brown from the algal bloom.

Within $10 \mathrm{~d}$, however, platelet ice in Q-0 began to melt from the center outwards. Divers estimated that approximately $50 \%$ of platelets were lost by 24 November (Fig. 3B). On 30 November, platelet layer thickness estimated by the depth transducer was still $45 \mathrm{~cm}$ (Fig. 2B), despite the virtual disappearance of platelet ice from everywhere in Q-0 but the periphery (Fig. 3C). The platelet layer remained intact beneath other quadrats through late December.

Because we planned to integrate standing crop and production under $1 \mathrm{~m}^{2}$ of ice, an accurate estimate of platelet layer thickness was essential. Thus, we calculated a 'mean' platelet thickness of $4.5 \mathrm{~cm}$ for Q-0 as of 30 November, based on an estimated $90 \%$ loss of platelets by that date. All standing crops and production estimates which follow are based on the more conservative estimate of platelet layer thickness at Q-0.

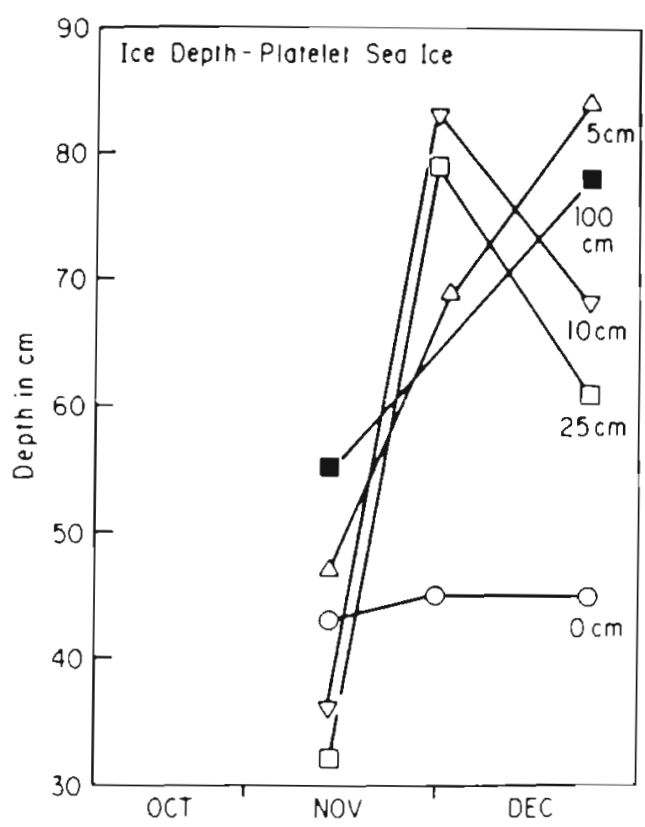

Fig. 2. Congelation and platelet ice thicknesses over the $78 \mathrm{~d}$ study. Snow cover depths: $(O) \mathrm{Q}-0 ;(\Delta) \mathrm{Q}-5 ;(\nabla) \mathrm{Q}-10 ;(\square) \mathrm{Q}-25 ;$ Q-100 

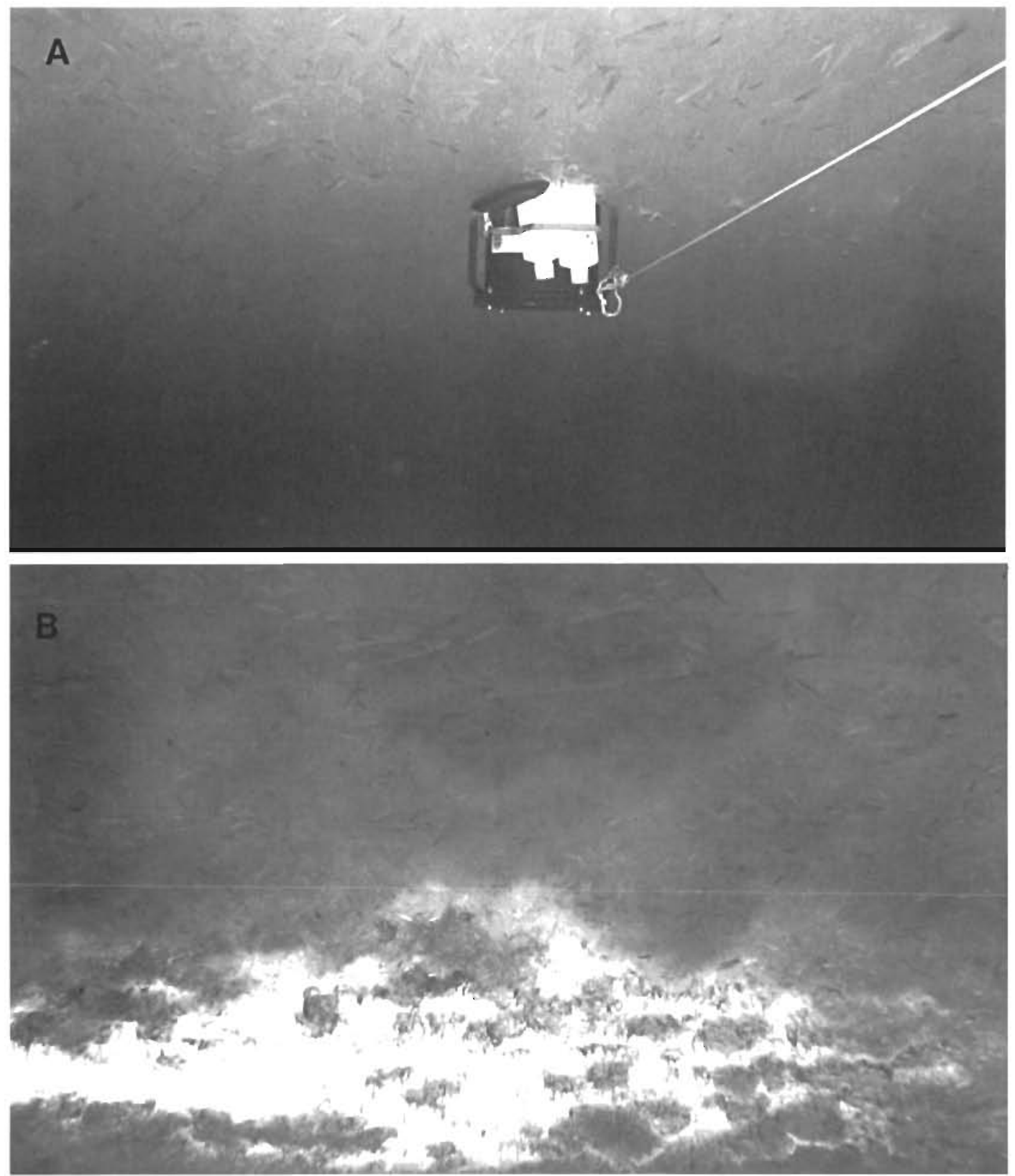

Fig. 3. Underwater photographs showing growth and demise of the platelet bloom beneath $Q-0$. (A) Spectroradiometer measuring irradiance beneath Q-5 on 9 Nov. (B) $50 \%$ platelet disappearance in Q-0 by 24 Nov

\section{Biomass}

Chl a standing crop in congelation ice at $\mathrm{Q}-0$ increased nearly 200 -fold, from 0.05 to $8.5 \mathrm{mg} \mathrm{m}^{-2}$ by mid-November, then declined to $1.2 \mathrm{mg} \mathrm{\textrm {m } ^ { - 2 }}$ by month's end (Fig. 4A, open circles). A second bloom developed in December, when strands of microalgae grew suspended from the ice undersurface (Fig. 3D). Growth of algae occurred sequentially in Q-5, Q-10 and Q-25; even under darkened Q-100, standing crop increased 4 -fold by late December.
Standing crop in the platelet layer (Fig. 4A, filled symbols) was approximately 10 times greater than in congelation sea ice, confirming visual observations by divers. Chl a biomass increased 850 -fold in Q-0, from 0.09 to $76 \mathrm{mg} \mathrm{m}^{-2} 5 \mathrm{wk}$ after snow removal, then declined as platelet ice disappeared by late November. Peak chl a standing crops in Q-0 were $76 \mathrm{mg} \mathrm{m}^{-2}$ in platelet and $9 \mathrm{mg} \mathrm{m}^{-2}$ in congelation ice, summing to a total of $85 \mathrm{mg} \mathrm{m}^{-2}$.

Phaeopigment concentrations increased over the study, from 0.01 to $2.6 \mathrm{mg} \mathrm{m}^{-2}$ in congelation and from 

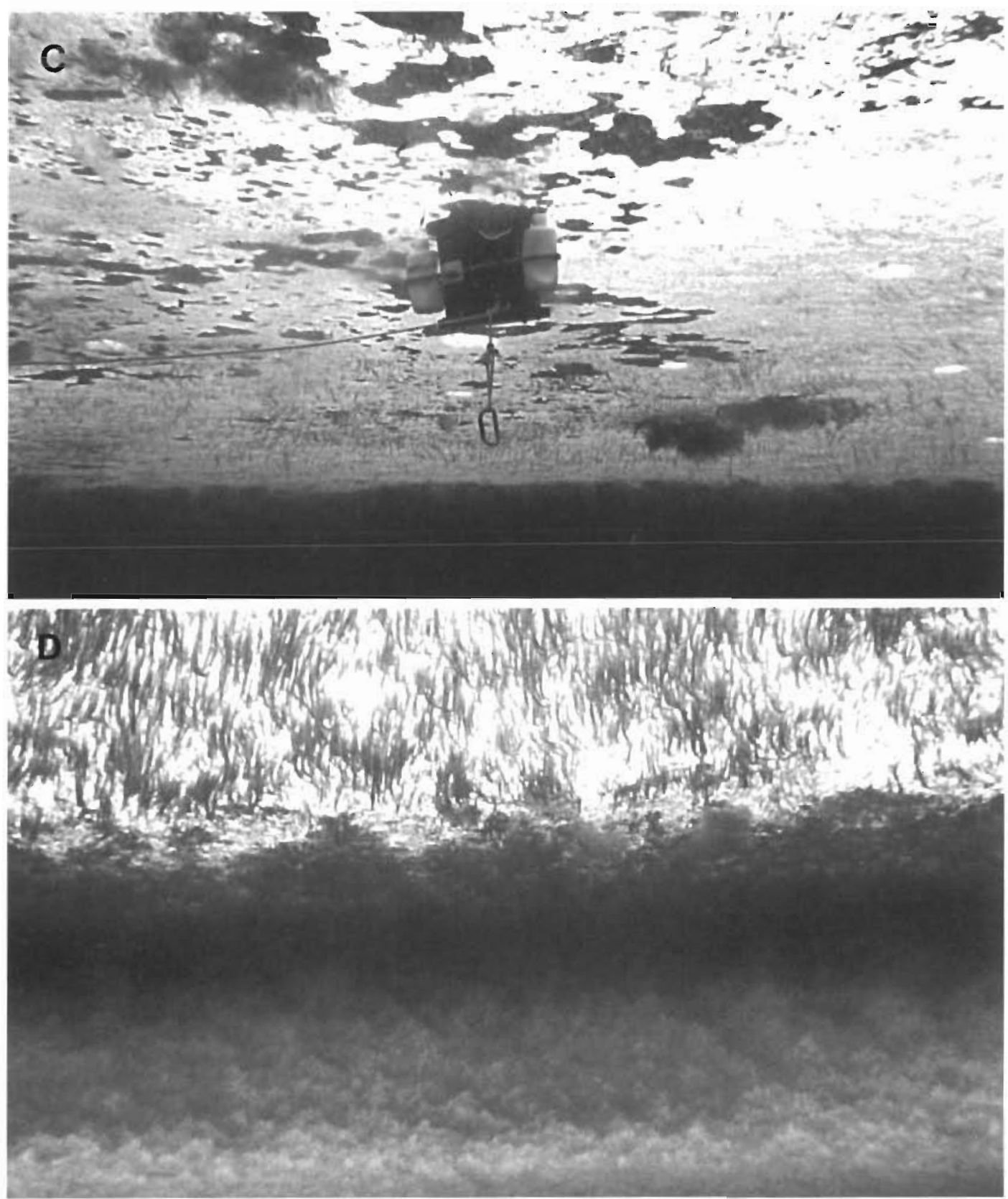

Fig. 3. (C) $90 \%$ disappearance of platelet layer beneath Q-0 by 30 Nov. (D) Strand community growing from undersurface of congelation ice in Q-0,20 Dec

0.07 to $11 \mathrm{mg} \mathrm{m}^{-2}$ in platelet ice at Q-0 (Fig. 4B). Chl a: phaeo ratios ranged from 1.3 to 7.9 in platelet ice and from 1.4 to 23.7 in congelation ice. Highest chl a: phaeo ratios, between 10 and 25, occurred in congelation ice at Q-0, Q-5 and Q-10 at the peak of their respective blooms; ratios remained below 5 in $\mathrm{Q}$ 25 and Q-100. The chl a: phaeo ratio declined in both platelet and congelation ice at Q-0 late in November, suggesting possible grazing of microalgae late in the season (SooHoo \& Kiefer 1982).
POC concentrations increased less markedly over the season than did chl a (Fig. 4C) and showed no clear trend with respect to snow cover. C: chl ratios were very high, ranging from 33 to 795 in platelet ice and from 131 to 6063 in congelation ice. Ratios were particularly high at the start of the experiment and beneath quadrats Q-25 and Q-100, suggesting a large background of detrital carbon in these samples. The C:chl ratio fell to 140 in sea ice at $Q-0$ by midNovember, due largely to the substantial increase in 

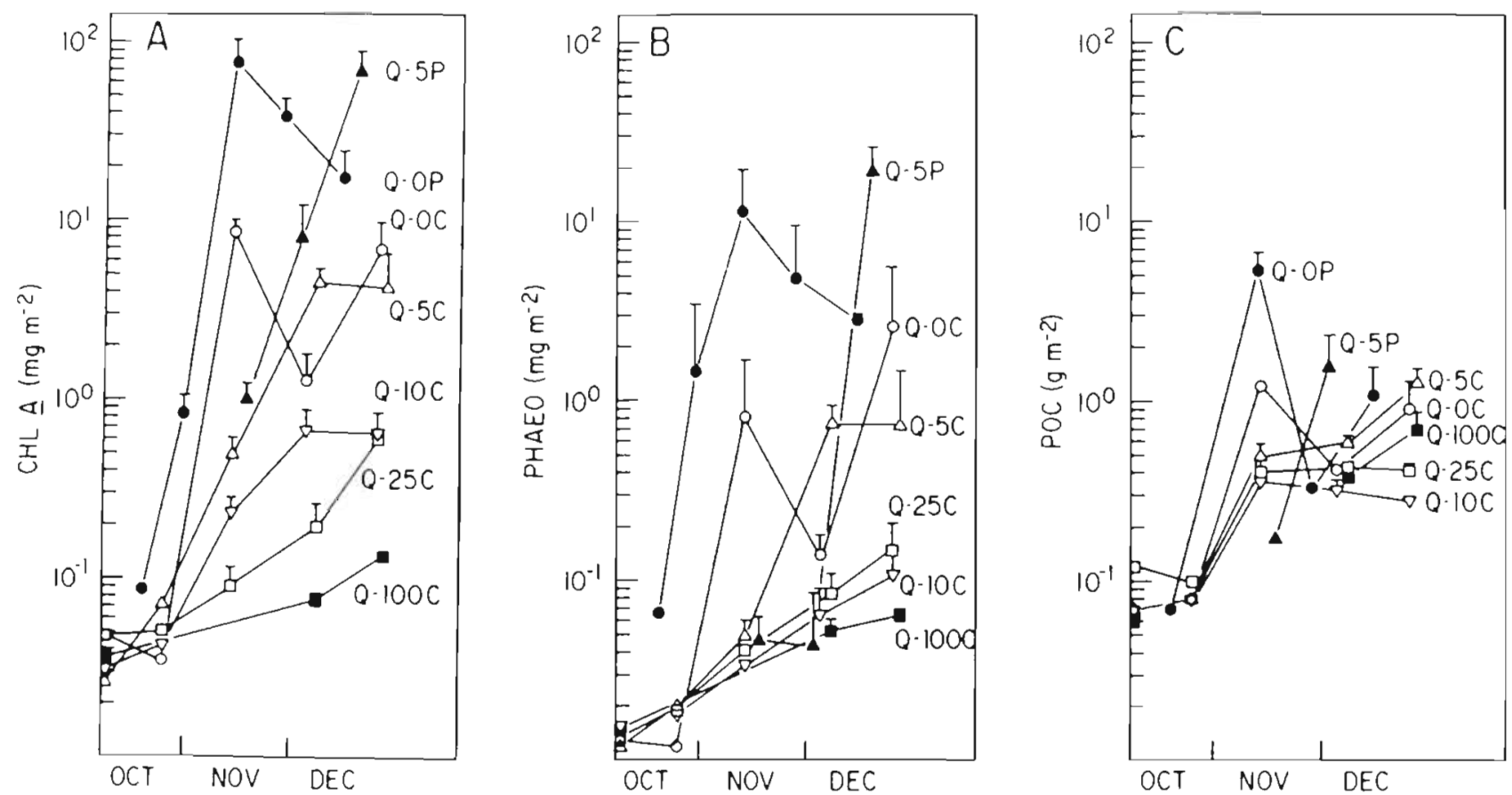

Fig. 4. Increases in concentration of (A) chlorophyll $a$, (B) phaeopigments and (C) particulate organic carbon over the $78 \mathrm{~d}$ study.

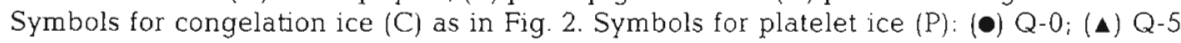

chl a. For calculation of cumulative production from chl a standing crop, we used a $\mathrm{C}$ :chl ratio of 38 reported previously for bottom sea ice microalgae (Sullivan et al. 1985).

Growth rates estimated from net increase in chl a during the first month after snow manipulation are plotted vs initial irradiance in Fig. 5. Growth rate in congelation ice tripled, from $0.03 \mathrm{~d}^{-1}$ in $\mathrm{Q}-100$ to $0.10 \mathrm{~d}^{-1}$ in $\mathrm{Q}-5$, with a 35 -fold increase in irradiance,

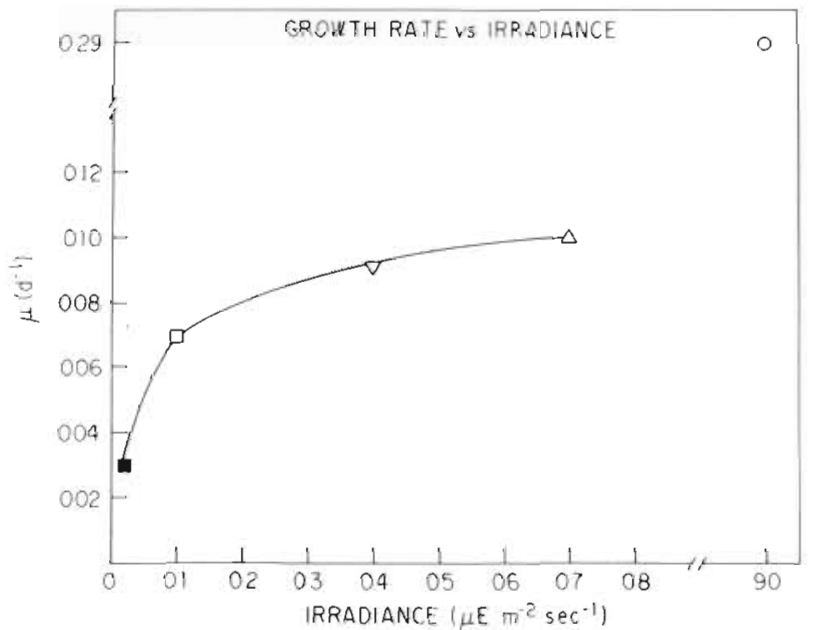

Fig. 5. Growth rates ( $\mu$ ) of ice algal communities, based on net accumulation of chlorophyll $a$ in congelation ice for 4 quadrats sampled over the first month of the study, plotted vs midday irradiance under each quadrat on 9 Nov. Symbols as in Fig. 2 then tripled again to $0.29 \mathrm{~d}^{-1}$ in $\mathrm{Q}-0$, with a further 100 -fold increase in irradiance. Growth rates in platelet ice (not shown), at $0.41 \mathrm{~d}^{-1}$ in $\mathrm{Q}-0$ and $0.13 \mathrm{~d}^{-1}$ in $\mathrm{Q}-5$, were $70 \%$ higher than those in congelation ice.

\section{Photosynthetic rate experiments}

Results of in situ photosynthetic rate experiments are given in Table 2. Irradiances are those measured with the scalar irradiance meter just prior to sample placement. Chlorophyll-normalized carbon fixation rates were highest in congelation ice at $Q-0$, between 1 and $2 \mathrm{mg} \mathrm{C}(\mathrm{mg} \text { chl })^{-1} \mathrm{~h}^{-1}$ in November. This quadrat had the highest downwelling irradiance of all experiments. Photosynthetic rate $\left(\mathrm{P}^{\mathrm{B}}\right)$ for congelation ice at both $\mathrm{Q}-0$ and Q-5 declined significantly late in December; platelet $\mathrm{P}^{\mathrm{B}}$, however, remained undiminished.

Daily primary production of microalgae associated with platelets in Q-0 increased from $1 \mathrm{mg} \mathrm{C} \mathrm{m}^{-2}$ in late October to a maximum $2100 \mathrm{mgC} \mathrm{m}^{-2}$ in early November. Assuming a growing season of $66 \mathrm{~d}$, this range of daily production provides an estimate of total spring production amounting to $38 \mathrm{~g} \mathrm{C} \mathrm{m}^{-2}$ (Table 3 ). By contrast, net production estimated from peak chl a standing crop, or from POC, was only 2.9 or $5.4 \mathrm{~g}$ $\mathrm{C} \mathrm{m}^{-2}$, respectively, suggesting that algae were lost from the platelet layer during the growing season. Divers observed pieces of diatom mat falling from Q-0 platelets into the water column as early as 
Table 2. Results of in situ photosynthetic rate experiments. Data represent the mean (range) of 2 replicates. Community: P. platelet; $C_{1}$ congelation; SW, seawater. Irr: irradiance $\left(\mu \mathrm{E} \mathrm{m}^{-2} \mathrm{~s}^{-1}\right)$ measured by scalar irradiance meter just prior to sample placement. $\mathrm{P}^{B}$; chlorophyll-specific photosynthetic rate in $\mathrm{mg} \mathrm{C}(\mathrm{mg} \mathrm{chl})^{-1} \mathrm{~h}^{-1}$. Prod: daily integrated production in $\mathrm{mg}^{\mathrm{C}} \mathrm{m}^{-2}$

\begin{tabular}{|c|c|c|c|c|c|}
\hline Quadrat & Date & Community & $\operatorname{Irr}$ & $\mathrm{P}^{B}$ & Prod \\
\hline $\mathrm{Q}-0$ & $\begin{array}{l}24 \text { Oct } \\
30 \text { Nov } \\
12 \text { Nov } \\
27 \text { Nov } \\
14 \text { Dec }\end{array}$ & $\begin{array}{l}P \\
P \\
P \\
P \\
P\end{array}$ & $\begin{array}{c}\text { ND } \\
59 \\
10 \\
6 \\
\text { ND }\end{array}$ & $\begin{array}{c}\text { ND } \\
0.006 \\
(0.003-0.009) \\
0.76 \\
(0.27-1.33) \\
0.49 \\
(0.27-0.71) \\
0.67\end{array}$ & $\begin{array}{c}28 \\
(20-32) \\
1 \\
(0-2) \\
2106 \\
(528-3408) \\
392 \\
(317-468) \\
200\end{array}$ \\
\hline $\mathrm{Q}-0$ & $\begin{array}{l}24 \mathrm{Oct} \\
12 \mathrm{Nov} \\
27 \mathrm{Nov} \\
14 \mathrm{Dec}\end{array}$ & $\begin{array}{l}\mathrm{C} \\
\mathrm{C} \\
\mathrm{C} \\
\mathrm{C}\end{array}$ & $\begin{array}{l}\text { ND } \\
183 \\
184 \\
\text { ND }\end{array}$ & $\begin{array}{c}\text { ND } \\
1.14 \\
(0.22-2.96) \\
1.95 \\
(0.9-3.0) \\
0.17 \\
(0.14-0.20) \\
(0.35-1.0)\end{array}$ & $\begin{array}{c}0.5 \\
(0.07-1.0) \\
84 \\
(77-89) \\
68 \\
(50-84) \\
13 \\
(9-16) \\
(161-240)\end{array}$ \\
\hline $\mathrm{Q}-0$ & $\begin{array}{l}22 \mathrm{Oct} \\
12 \mathrm{Nov} \\
17 \mathrm{Dec} \\
27 \mathrm{Dec}\end{array}$ & $\begin{array}{l}\text { SW } \\
\text { SW } \\
\text { SW } \\
\text { SW }\end{array}$ & $\begin{array}{l}\text { ND } \\
\text { ND } \\
\text { ND } \\
\text { ND }\end{array}$ & $\begin{array}{l}0.21 \\
1.12 \\
0.60 \\
2.30\end{array}$ & $\begin{array}{r}1.0 \\
50.5 \\
45.5 \\
4869.2\end{array}$ \\
\hline$Q-5$ & $\begin{array}{r}17 \text { Nov } \\
2 \mathrm{Dec} \\
18 \mathrm{Dec}\end{array}$ & $\begin{array}{l}P \\
P \\
P\end{array}$ & $\begin{array}{r}6 \\
\text { ND } \\
3\end{array}$ & $\begin{array}{c}0.09 \\
(0.04-0.14) \\
0.24 \\
(0.18-0.31) \\
0.20 \\
(0.16-0.24)\end{array}$ & $\begin{array}{c}2 \\
(1-3) \\
75 \\
(58-91) \\
314 \\
(293-334)\end{array}$ \\
\hline$Q-5$ & $\begin{array}{r}17 \mathrm{Nov} \\
2 \mathrm{Dec} \\
18 \mathrm{Dec}\end{array}$ & $\begin{array}{l}C \\
C \\
C\end{array}$ & $\begin{array}{l}\text { ND } \\
\text { ND } \\
\text { ND }\end{array}$ & $\begin{array}{c}0.06 \\
(0.03-0.09) \\
0.41 \\
(0.16-0.66) \\
0.09\end{array}$ & $\begin{array}{c}0.6 \\
(0.5-0.7) \\
10 \\
(8-13) \\
19\end{array}$ \\
\hline
\end{tabular}

9 November, even before the occurrence of widespread platelet melting.

For congelation ice at $\mathrm{Q}-0$, daily production rates (Table 2) were 10 -fold lower than for platelet ice, leading to a seasonal production estimate of $3.4 \mathrm{~g} \mathrm{C} \mathrm{m}^{-2}$ (Table 3). This estimate may be low because it was based on sampling only the bottom $5 \mathrm{~cm}$ of congelation ice. Yet it was still higher than the $0.3(1.2) \mathrm{g} \mathrm{C} \mathrm{m}^{-2}$ estimated from peak chl a (POC) standing crop in $25 \mathrm{~cm}$ of bottom ice.

Seasonal production at $\mathrm{Q}-5$ was estimated at $3.8 \mathrm{~g} \mathrm{C}$ $\mathrm{m}^{-2}$ for platelet ice and $0.3 \mathrm{~g} \mathrm{C} \mathrm{m}^{-2}$ for congelation ice (Table 3). These estimates were more comparable to net production estimates based on chl a of 2.6 and $0.2 \mathrm{~g}$ C $\mathrm{m}^{-2}$ respectively.

Daily production in seawater increased from $0.001 \mathrm{~g}$ $\mathrm{C} \mathrm{m}^{-2}$ in early October to $4 \mathrm{~g} \mathrm{C} \mathrm{m}^{-2}$ in late December (Table 2), when a bloom of Phaeocystis pouchetii occurred in the water column. Seawater production averaged $2 \mathrm{~g} \mathrm{C} \mathrm{m}^{-2}$ over the last $9 \mathrm{~d}$ of the experiment, leading to a spring production total of $24.4 \mathrm{~g} \mathrm{C} \mathrm{m}^{-2}$ (Table 3).

\section{DISCUSSION}

\section{Comparison of production estimates}

Bottom sea ice habitats have been described as refugia for microalgal growth, where production accumulates unrestricted by losses due to grazing or sinking (Bunt 1963, Meguro et al. 1967, Bunt \& Lee 1970, Sullivan et al. 1985). Thus, we hypothesized that algal biomass in sea ice should approximate cumulative production, although recognizing that we made a conservative estimate for several reasons (Sullivan et al. 1985). Results presented here show that previous 
Table 3. Seasonal production ( $\mathrm{g} \mathrm{C} \mathrm{m}^{-2}$ ) derived from temporally integrated photosynthetic rate experiments (Cum prod) and from accumulation of algal biomass (Net prod). Community: P, platelet; $C$, congelation; SW, seawater. MDP: mean daily production

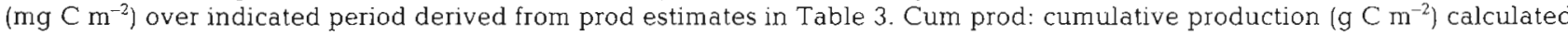
as the product of MDP and number of days. Net prod: production based on chl a and POC standing crops. Chl a converted to carbon using C:chl a ratio of 38 (Sullivan et al. 1985). Spring production estimates derived from cumulative production and peak algal biomass are underlined

\begin{tabular}{|c|c|c|c|c|c|c|}
\hline \multirow[t]{2}{*}{ Community } & \multirow[t]{2}{*}{ Period } & \multirow[t]{2}{*}{ MDP } & \multirow[t]{2}{*}{ Cum prod } & \multicolumn{2}{|c|}{ Net prod } & \multirow[t]{2}{*}{ Date } \\
\hline & & & & $\operatorname{chl} a$ & POC & \\
\hline $\mathrm{Q}-0 \mathrm{P}$ & $\begin{array}{l}9 \text { Oct-24 Oct } \\
24 \text { Oct-30 Oct } \\
30 \text { Oct-12 Nov } \\
12 \text { Nov-27 Nov } \\
27 \text { Nov-14 Dec }\end{array}$ & $\begin{array}{c}28 \\
14.5 \\
1053.5 \\
1249 \\
296\end{array}$ & $\begin{array}{r}0.420 \\
0.507 \\
14.203 \\
32.938 \\
37.970 \\
\end{array}$ & $\begin{array}{l}0.003 \\
0.315 \\
2.903 \\
1.448 \\
0.654\end{array}$ & $\begin{array}{l}0.07 \\
\text { ND } \\
5.37 \\
0.33 \\
1.07\end{array}$ & $\begin{array}{l}19 \text { Oct } \\
30 \text { Oct } \\
13 \text { Nov } \\
27 \text { Nov } \\
14 \text { Dec }\end{array}$ \\
\hline $\mathrm{Q}-0 \mathrm{C}$ & $\begin{array}{l}9 \text { Oct-24 Oct } \\
24 \text { Oct-12 Nov } \\
12 \text { Nov-27 Nov } \\
27 \text { Nov-14 Dec }\end{array}$ & $\begin{array}{l}0.5 \\
84.5 \\
76 \\
40.5\end{array}$ & $\begin{array}{l}0.008 \\
1.613 \\
2.753 \\
3.442 \\
\end{array}$ & $\begin{array}{l}0.001 \\
0.329 \\
0.048 \\
0.265\end{array}$ & $\begin{array}{l}0.08 \\
1.22 \\
0.42 \\
0.91\end{array}$ & $\begin{array}{r}25 \text { Oct } \\
13 \text { Nov } \\
4 \text { Dec } \\
24 \text { Dec }\end{array}$ \\
\hline $\mathrm{Q}-0 \mathrm{SW}$ & $\begin{array}{c}9 \text { Oct-22 Oct } \\
22 \text { Oct-12 Nov } \\
12 \text { Nov-17 Dec } \\
17 \text { Dec-27 Dec }\end{array}$ & $\begin{array}{c}1.0 \\
25.75 \\
48 \\
2457.4\end{array}$ & $\begin{array}{r}0.013 \\
0.554 \\
2.234 \\
24.350\end{array}$ & $\begin{array}{l}\text { NA } \\
\text { NA } \\
\text { NA } \\
\text { NA }\end{array}$ & $\begin{array}{l}\mathrm{NA} \\
\mathrm{NA} \\
\mathrm{NA} \\
\mathrm{NA}\end{array}$ & \\
\hline $\mathrm{Q}-5 \mathrm{P}$ & $\begin{array}{l}9 \text { Oct-17 Nov } \\
17 \text { Nov-2 Dec } \\
2 \text { Dec-18 Dec }\end{array}$ & $\begin{array}{r}2 \\
38.5 \\
194.5\end{array}$ & $\begin{array}{l}0.078 \\
0.656 \\
3.768 \\
\end{array}$ & $\begin{array}{l}0.039 \\
0.308 \\
2.643 \\
\end{array}$ & $\begin{array}{l}0.17 \\
1.55 \\
\text { ND }\end{array}$ & $\begin{array}{r}17 \text { Nov } \\
2 \mathrm{Dec} \\
18 \mathrm{DeC}\end{array}$ \\
\hline$Q-5 C$ & $\begin{array}{l}9 \text { Oct-17 Nov } \\
17 \text { Nov-2 Dec } \\
2 \text { Dec-18 Dec }\end{array}$ & $\begin{array}{r}0.6 \\
5.3 \\
14.5\end{array}$ & $\begin{array}{l}0.023 \\
0.103 \\
0.335 \\
\end{array}$ & $\begin{array}{l}0.019 \\
0.172 \\
0.160 \\
\end{array}$ & $\begin{array}{l}0.50 \\
0.59 \\
1.26 \\
\end{array}$ & $\begin{array}{r}13 \text { Nov } \\
7 \text { Dec } \\
26 \text { Dec }\end{array}$ \\
\hline
\end{tabular}

work may have grossly underestimated sea ice production. At $Q-0$, production based on algal biomass was only one tenth that estimated from temporally integrated in situ $\mathrm{NaH}^{14} \mathrm{CO}_{3}$ incorporation into particulate material.

Underwater observations suggested reasons for the disparity. Microalgae were lost from Q-0 beginning in mid-November. Most loss was due to widespread platelet melting, but divers also noted that currents, e.g. caused by tidal action and swimming seals, promoted the transfer of platelet microalgae into the water column. Grazing losses were inferred from a decline in the chl a:phaeo ratio late in November. Divers observed that amphipods, pteropods and fish appeared to congregate beneath Q-0, apparently attracted to the light or high algal biomass. Likewise, microzooplankton were more abundant in Q-0 than in other quadrat samples (G. T. Taylor unpubl. data).

Despite significant losses, microalgae in Q-0 maintained high rates of production throughout the $10 \mathrm{wk}$ study. Total spring production based on $\mathrm{NaH}^{14} \mathrm{CO}_{3}$ incorporation was $38 \mathrm{~g} \mathrm{C} \mathrm{m}^{-2}$ in platelet and $3 \mathrm{~g} \mathrm{C} \mathrm{m}^{-2}$ in congelation ice, summing to a total of $41 \mathrm{~g} \mathrm{C} \mathrm{m}^{-2}$. This figure, though it greatly exceeds previous estimates for sea ice production in McMurdo Sound
(Table 4), must nevertheless be considered conservative, because a strand community which grew suspended from the bottom of congelation ice (Fig. 3B) in December was not adequately sampled either by SIPRE auger or by divers using buckets to obtain platelet ice. A similar community from East Antarctica has been described (McConville \& Wetherbee 1983) for which in situ rates of production ranged from 1.6 to $33 \mathrm{mg} \mathrm{C} \mathrm{m}^{-2} \mathrm{~h}^{-1}$ in December 1982 (McConville et al. 1985). Assuming only $12 \mathrm{~h}$ of light per day, results from McConville et al. (1985) provide an estimate for cumulative production by the strand community of $1.8 \mathrm{~g} \mathrm{C} \mathrm{m}^{-2}$ in $12 \mathrm{~d}$.

Algal biomass in Q-5 more closely approximated cumulative production (Table 3), presumably because ice in Q-5 did not begin to melt until late December. Our observations of varying platelet integrity dependent on snow cover were in good agreement with those of Bunt \& Lee (1970). Platelet ice at their Station A, under 'continuous' snow cover, reached a maximum thickness of $2 \mathrm{~m}$ by mid-October, whereas at snow-free Station $\mathrm{H}$ the platelet layer decreased from $1 \mathrm{~m}$ to $5 \mathrm{~cm}$ between 4 and 20 November.

Our results suggest that production assessments based on algal standing crop may seriously underesti- 
Table 4. Spring production estimates $\left(\mathrm{g} \mathrm{C} \mathrm{m}^{-2}\right)$ derived from biomass accumulation and in situ photosynthetic rate (PSR) in platelet and bottom congelation ice communities at McMurdo Sound, Antarctica

\begin{tabular}{|c|c|c|c|c|c|}
\hline Year & Stn & Snow depth & Biomass & PSR & Source \\
\hline \multicolumn{6}{|l|}{ Platelet ice } \\
\hline 1967 & $\mathrm{H}$ & $0 \mathrm{~cm}$ & 0.5 & - & Bunt \& Lee (1970) \\
\hline 1982 & $Q-0$ & $0 \mathrm{~cm}$ & 2.9 & 38.0 & This study \\
\hline 1967 & A & Continuous & 1.1 & - & Bunt \& Lee (1970) \\
\hline 1982 & $Q-5$ & $5 \mathrm{~cm}$ & 2.6 & 3.8 & This study \\
\hline \multicolumn{6}{|c|}{ Congelation ice } \\
\hline 1980 & Mean & $0-2 \mathrm{~cm}$ & 4.1 & - & Palmisano \& Sullivan (1983) \\
\hline 1981 & Mean & $0-25 \mathrm{~cm}$ & 4.9 & - & Sullivan et al. (1985) \\
\hline 1982 & $\mathrm{Q}-0$ & $0 \mathrm{~cm}$ & 0.3 & 3.4 & This study \\
\hline 1982 & $\mathrm{Q}-5$ & $5 \mathrm{~cm}$ & 0.2 & 0.3 & This study \\
\hline
\end{tabular}

mate cumulative production, particularly in snow-free ice. This bias can lead to erroneous conclusions concerning the ability of ice microalgae to increase productivity under increased light. Peak standing crops in Q-0 and Q-5 both were approximately $3 \mathrm{~g} \mathrm{C} \mathrm{m}^{-2}$; however, total production in Q-0 was 6-fold higher. By contrast, Bunt \& Lee (1970) estimated from algal biomass that net annual production at snow-free Station $\mathrm{H}$ was only half that at Station A (Table 4). Because light snowfall and strong surface winds typically keep large areas of McMurdo Sound free of snow cover, mean production estimates based on chlorophyll standing crop (e.g. Palmisano \& Sullivan 1983, Sullivan et al. 1985) must be revised upward

Algal biomass associated with congelation ice in 1982 was 10-fold lower than in 1980 and 1981 (Table 4), years in which the platelet layer was absent (Sullivan et al. 1982). Platelet ice may restrict seawater influx to congelation ice, limiting colonization from the water column. Restricted seawater exchange might also lead to nutrient depletion as the algal bloom develops, Palmisano \& Sullivan (1985) presented independent evidence of nutrient limitation in the McMurdo sea ice algal community. Photosynthetic rate $\left(\mathrm{P}^{\mathrm{B}}\right)$ in congelation ice decreased sharply in December, suggesting algal senescence.

Seawater production beneath Q-0 was Jess than $1 \%$ that in sea ice until late December, when mean productivity increased sharply to $>2 \mathrm{~g} \mathrm{C} \mathrm{m}^{-2} \mathrm{~d}^{-1}$. The increase was due to a nearly unialgal bloom of Phaeocystis pouchetii in the water column; at the same time, the sea ice habitat of the microalgal community was disintegrating. Between 20 and 27 December nearly all platelets beneath quadrats disappeared, and divers observed a layer of freshwater extending 15 to $30 \mathrm{~cm}$ below the ice. Microalgae still attached to sea ice changed pigmentation from brown to green, while crustaceans in the freshwater layer appeared dead, presumably the result of severe osmotic stress. $P$. pouchetii colonies were uniformly distributed throughout the depth of seawater underlying the freshwater layer.

Estimates of annual phytoplankton production in the Southern Ocean range from 16 to $100 \mathrm{~g} \mathrm{C} \mathrm{m}^{-2}$ (Ryther 1969, El-Sayed 1978, Smith \& Nelson 1986), with daily rates of production often exceeding $2 \mathrm{~g} \mathrm{C} \mathrm{m}^{-2}$ in neritic and upwelling areas (Heywood \& Whitaker 1984). When we add water column to sea ice production measured in this study, our results indicate a total production potential in McMurdo Sound of $65 \mathrm{~g} \mathrm{C} \mathrm{m}^{-2}$ under snow-free ice during spring alone.

\section{Effect of light on microalgal growth}

The second objective of this study was to test the influence of the in situ under-ice light field on growth of ice microalgae. An initial 4500-fold gradient in under-ice irradiance among quadrats affected both onset and growth rate of the microalgal bloom. Within 3 wk of snow removal, platelet ice at Q-0 acquired a golden-brown hue characteristic of diatom blooms. Sequentially, ice beneath Q-5, Q-10 and Q-25 became discolored; platelets beneath Q-100 remained colorless throughout the study.

A conservative estimate of growth rate (u) was calculated from the rate of chlorophyll accurnulation in congelation ice; platelet ice, unfortunately, was not sampled beneath all quadrats. We suggest that the 3 fold increase in growth rate between Q-100 and Q-5 (Fig. 5) was due to a physiological response by microalgae to increased light. A second tripling in growth rate associated with increased irradiance, however, to $0.29 d^{-1}$ beneath Q-0, was accompanied by a substantial change in species composition beneath the snowcleared quadrat (Grossi \& Sullivan unpubl.).

The estimated $\mu$ of $0.1 \mathrm{~d}^{-1}$ beneath $\mathrm{Q}-5$ is similar to that reported for microalgae in congelation ice under 
$7 \mathrm{~cm}$ snow cover in 1981 (Grossi et al. 1984). Pennate diatoms, including the colonial species Nitzschia stellata Manguin and Amphiprora kufferathii Manguin, dominated assemblages both in 1981 and in all quadrats but Q-0 in 1982 (Grossi et al. 1984, Grossi 1985). At Q-0, Thalassiosira antarctica Comber and Nitzschia closterium Wm. Smith dominated the initial bloom; a chain-forming Fragilaria sp., tube-dwelling Berkeleya sp. and Chaetoceros sp. were most abundant in late season samples (Grossi 1985).

The bottom ice community is generally considered to be shade-adapted (Bunt 1964). Booth (1984), studying bottom pack ice algae in the Arctic, found that in situ photosynthetic rate was 2 to 3 orders of magnitude lower at light intensities $>20 \mu \mathrm{E} \mathrm{m}^{-2} \mathrm{~s}^{-1}$ than at intensities $<4 \mu \mathrm{E} \mathrm{m} \mathrm{m}^{-2} \mathrm{~s}^{-1}$. Palmisano et al. (1985b), from short-term photosynthesis-irradiance experiments at McMurdo Sound in 1983, found that congelation ice algae were photo-inhibited at irradiances above $25 \mu \mathrm{E} \mathrm{m}^{-2} \mathrm{~s}^{-1}$. Cota (1985), also from photosynthesis-irradiance experiments, observed for sea ice microalgae in the Canadian Arctic that both biomass and maximum $\mathrm{P}^{\mathrm{B}}$ were lowest in a snow-cleared area; highest $\mathrm{P}^{\mathrm{B}}$ was measured in sea ice under $11 \mathrm{~cm}$ snow at an optimal irradiance of $8.5 \mu \mathrm{E} \mathrm{m} \mathrm{m}^{-2} \mathrm{~s}^{-1}$. Furthermore, he reported that an apparent microalgal growth rate calculated from increase in chlorophyll a was $64 \%$ higher under sea ice with moderate to heavy snow cover than for sea ice under little or no snow.

By contrast, microalgae in our study grew fastest, reached highest standing crop and demonstrated maximum $\mathrm{P}^{\mathrm{B}}$ in the snow-cleared quadrat, where ambient irradiance was close to $100 \mu \mathrm{E} \mathrm{m}^{-2} \mathrm{~s}^{-1}$. Several factors may contribute to our divergent result. First, unlike previous investigators, we sampled quadrats repetitively over a 3 mo period, including the early rapid phase of bloom development. Palmisano et al. (1985b) cautioned that low $\mathrm{P}^{\mathrm{B}}$ values they obtained may have reflected a senescent algal community.

Second, because snow manipulation was effected early in the season when algal biomass was low, the light gradient apparently selected for different species assemblages under the snow-cleared and snowcovered quadrats. Full details on floristics composition in sea ice beneath quadrat areas will be presented elsewhere (Grossi \& Sullivan unpubl.).

Finally, our approach included extensive underwater observations as well as surface sampling. Without knowledge of the physical changes which occurred in platelet ice beneath Q-0, it would have been difficult to suggest reasons for the disparity in production estimates derived from biomass and in situ photosynthetic rate.

Here we have shown that algal biomass in sea ice is not an adequate approximation of cumulative produc- tion, particularly at snow-free sites. This finding, which contradicts an assumption upon which previous estimates of production in McMurdo Sound have been based, demonstrates the value of using an experimental approach to study sea ice ecology. It also sharply revises upward the estimate of primary production in McMurdo Sound.

Acknowledgements. The authors thank Dr. Anna C. Palmisano for field assistance, and Dr. Palmisano, Mr. Michael Lizotte and Dr. Janice SooHoo for critically reviewing the manuscript. The US Naval Support Force in Antarctica and ITT Antarctic Services provided logistics support. Mr. John Wood assisted with dives. This study was funded by National Science Foundation grant DPP 81-17237 to CWS.

\section{LITERATURE CITED}

Ackley, S. F., Buck, K. R., Taguchi, S. (1979). Standing crop of algae in the sea ice of the Weddell Sea Region. Deep Sea Res. 26A: 269-281

American Public Health Association (1971). Standard methods for the analysis of waters and wastewater. 13th edn. Washington, D.C.

Apollonio, S. (1961). The chlorophyll content of Arctic sea-ice. Arctic 14: 197-200

Booth, J. A. (1984). The epontic algal community of the ice edge zone and its significance to the Davis Strait ecosystem. Arctic 37: 234-243

Bunt, J. S. (1963). Diatoms of Antarctic sea-ice as agents of primary production. Nature, Lond. 199: 1225-1257

Bunt, J. S. (1964). Primary production under sea ice in Antarctic waters. 2. Influence of light and other factors on photosynthetic activities of Antarctic marine microalgae. Antarct. Res. Ser. 1: 27-31

Bunt, J. S. (1971). Microbial productivity in the polar regions. Symposia of the Society for General Microbiology XXI. Microbes and Biological Productivity, p. 333-353

Bunt, J. S., Lee, C. C. (1970). Seasonal primary production in Antarctic sea ice at McMurdo Sound in 1967. J. mar. Res. 28: $304-320$

Bunt, J. S., Wood, E. J. F. (1963). Microalgae and Antarctic sea ice. Nature, Lond. 199: 1254-1255

Burkholder, P. R., Mandelli, E. F. (1965). Carbon assimilation of marine phytoplankton in Antarctica. Proc. natn. Acad. Sci. U.S.A. $54: 437-440$

Cota, G. F. (1985). Photoadaptation of high arctic ice algae. Nature, Lond. 315: 219-222

El-Sayed, S. Z. (1978). Primary productivity and estimates of potential yields in the Southern Ocean. In: McWhinnie, M. A. (ed.) Polar research to the present and future. West View Press, Boulder, Colorado, p. 141-160

Fogg, G. E. (1977). Aquatic primary production in the Antarctic. Phil. Trans. R. Soc. Lond. B. Biol. Sci. 279: 27-38

Grossi, S. MCG. (1985). Response of a sea ice microalgal community to a gradient in under ice irradiance. Ph.D. dissertation, Univ. of Southern California, Los Angeles

Grossi, S. McG., Kottmeier, S. T., Sullivan, C. W. (1984). Sea ice microbial communities III. Seasonal abundance of microalgae and associated bacteria, McMurdo Sound, Antarctica. Microb. Ecol. 10: 231-242

Heywood, R. B., Whitaker, T. M. (1984). The antarctic marine flora. In: Laws, R. M. (ed.) Antarctic ecology. Gulf Publishing Co., Houston, p. 373-419 
Holm-Hansen, O, Lorenzen, C. J., Holmes, R. W., Strickland, J. D. H. (1965). Fluorometric determination of chlorophyll. J. Cons. perm. int. Explor. Mer. 30: 3-15

Hormer, R., Alexander, V. (1972). Algal populations in Arctic sea ice: an investigation of heterotrophy. Limnol Oceanogr. 17: 454-458

Horner, R., Schrader, G. C. (1982). Relative contributions of ice algae, phytoplankton, and benthic microalgae to primary production in nearshore regions of the Beaufort Sea. Arctic 35: 484-503

Hoshiai, T. (1977). Seasonal change of ice communities in the sea ice near Syowa Station, Antarctica. In: Dunbar, M. J. (ed.) Polar Oceans. Polar Institute of North America, Arlington, Virginia, p. 307-317

Kottmeier, S. T., Grossi, S. M., Sullivan, C. W. (1987). Sea ice microbial communities. VIII. Bacterial production in annual sea ice of McMurdo Sound, Antarctica. Mar. Ecol. Prog. Ser. 35: 175-186

Maykut, G. A., Grenfell, T. C. (1975). The spectral distribution of light beneath first-year sea ice in the Arctic Ocean. Limnol. Oceanogr. 20: 554-563

McConville, M. J., Mitchell, C., Wetherbee, R. (1985) Patterns of carbon assimilation in a microalgal community from annual sea ice, East Antarctica. Polar Biol. 4: 135-141

McConville, M. J., Wetherbee, R. (1983). The bottom ice microalgal community from annual ice in the inshore waters of East Antarctica. J. Phycol. 19: 431-439

Meguro, H. (1962). Plankton ice in the Antarctic Ocean. Antarctic Rec. 14: 1192-1199

Meguro, H., Ito, K., Fukushima, H. (1967). Ice flora (Bottom Type): a mechanism of primary production in polar sea and the growth of diatoms in sea ice. Arctic 20: 114-133

Menzel, D. W., Vaccaro, R. F. (1964). The measurement of dissolved organic and particulate carbon in seawater. Limnol. Oceanogr. 9: 138-142

Palmisano, A. C., Kottmeier, S. T., Moe, R. L., Sullivan, C. W (1985a). Sea ice microbial communities. IV. The effect of light perturbation on microalgae at the ice-seawater interface in McMurdo Sound, Antarctica. Mar. Ecol. Prog. Ser. 21: $37-45$

Palmisano, A. C., SooHoo, J. B., Moe, R. L., Sullivan, C. W. (1987). Sea ice microbial communities. VII. Changes in under-ice spectral irradiance during the development of Antarctic sea ice microalgal communities. Mar. Ecol. Prog. Ser. 35: 165-173

Palmisano, A. C., SooHoo, J. B., Sullivan, C. W. (1985b) Photosynthesis-irradiance relationships in sea ice micro algae from McMurdo Sound, Antarctica. J, Phycol. 21: 341-346

Palmisano, A. C., Sullivan, C. W. (1982). Physiology of sea ice diatoms. I. Response of three polar diatoms to a simulated summer-winter transition. J. Phycol. 18: 489-498

Palmisano, A. C., Sullivan, C. W (1983). Sea ice microbial communities (SIMCO): I. Distribution, abundance, and primary production of ice microalgae in McMurdo Sound, Antarctica in 1980. Polar Biol. 2: 171-177

Palmisano, A. C., Sullivan, C. W. (1985). Pathways of photosynthetic carbon assimilation in sea ice algae from McMurdo Sound, Antarctica. Limnol. Oceanogr. 30: 674-678

Ryther, J. H. (1969). Photosynthesis and fish production in the sea. Science 166: 72-76

Silver, M. W., Davoll, P. J. (1978). Loss of ${ }^{14} \mathrm{C}$ activity after chemical fixation of phytoplankton: error source for autoradiography and other productivity measurements. Limnol. Oceanogr. 23: 362-368

Smith, W. O., Jr., Nelson, D. M. (1986). Importance of ice edge phytoplankton production in the southern ocean. Bioscience 36 (4): $251-257$

SooHoo, J. B., Kiefer, D. A. (1982). Vertical distribution of phaeopigments - I. A simple grazing and photooxidative scheme for small particles. Deep Sea Res. 29: 1539-1551

Steeman-Nielsen, E. (1952). The use of radioactive carbon $\left({ }^{14} \mathrm{C}\right)$ for measuring organic production in the sea. J. Cons. perm. int. Explor. Mer. 18: 117-140

Strickland, J. D. H., Parsons, T. R. (1972). A practical handbook of sea water analysis, 2nd edn. Bull. Fish Res. Bd Can. 167

Sullivan, C. W., Palmisano, A. C., Kottmeier, S. T., Grossi, S. M., Moe, R. (1985). The influence of light on growth and development of the sea-ice microbial community of McMurdo Sound. In: Siegfried, R. (ed.) Food webs and nutrient cycles. Springer-Verlag, New York, p. 78-83

Sullivan, C. W., Palmisano, A. C., Kottmeier, S. T., Moe, R. L. (1982). Development of the sea ice microbial community (SIMCO) in McMurdo Sound, Antarctica. Antarct. J. U.S. 17: $155-157$

Sullivan, C. W., Palmisano, A. C., SooHoo, J. B. (1984). Influence of sea ice and sea ice biota on downwelling irradiance and spectral composition of light in McMurdo Sound. In: Blizard, M. (ed.) Ocean optics VII. Proc. Int. Soc. of Optical Engineers 489: 159-165

Wood, R. D. (1975). Hydrobotanical methods. University Park Press, Baltimore 